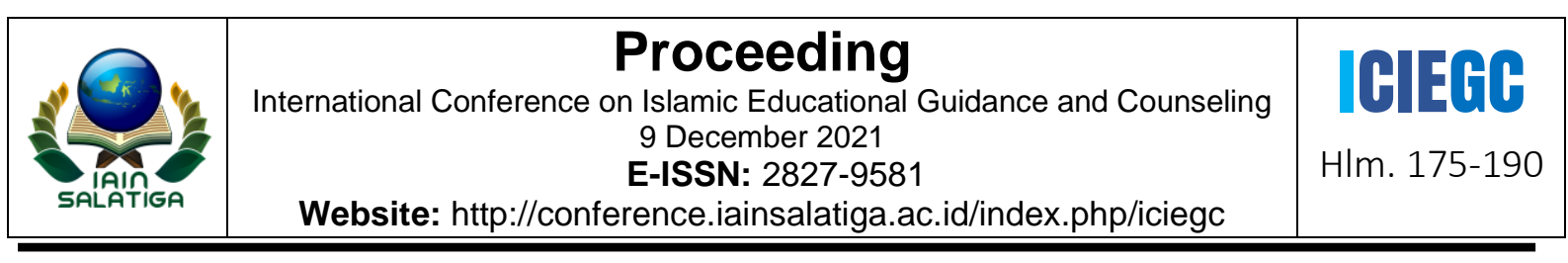

\title{
BIMBINGAN BELAJAR BERBASIS GAYA BELAJAR UNTUK MENINGKATKAN HASIL BELAJAR MATA PELAJARAN MATEMATIKA
}

\author{
Lilik Sriyanti $^{1}$, Ina Kurniati ${ }^{2}$
}

${ }^{1,2}$ Institut Agama Islam Negeri Salatiga

\begin{tabular}{l}
\hline Informasi Artikel \\
\hline Penulis Korespondensi: \\
Lilik Sriyanti, \\
Email: \\
lilik_s@iainsalatiga.ac.id
\end{tabular}

\begin{abstract}
Mathematics is still seen as a difficult and uninteresting subject, therefore it requires certain strategies so that learning outcomes are optimal. Guidance Counseling as part of the element of education contributes to supporting learning objectives. Learning style-based learning is seen as one of the solutions to improve mathematics learning outcomes. This study aims to describe the application of learning style-based learning guidance that is able to improve mathematics learning outcomes and to test the effectiveness of learning style-based tutoring in improving mathematics learning outcomes. This study uses a mix method approach with a one-group pretest-posttest design. Qualitative data obtained through questionnaires, observations and interviews during the implementation of learning guidance. Quantitative data obtained from learning outcomes tests before and after learning guidance activities. Data analysis was performed using descriptive statistics and t-test. The results showed that prior to the implementation of earning guidance services, students did not know their learning styles, how to learn self-taught, students were less interested in mathematics and considered mathematics a difficult subject. Mathematics learning outcomes tend to be low. The implementation of earning guidance is carried out in stages: assessing student learning styles, providing information and discussions about learning style-based learning strategies, practicing learning stylebased learning strategies. Through tutoring based on learning styles, students become more interested in learning mathematics and there is an increase in learning outcomes from the average pretest 46.25 to 80.63 . The results of the t-test of 11.296 with a significance level of $0.5 \%$. Thus, guidance learning style-based is effective in improving mathematics learning outcomes, so mathematics teachers need to teach learning style-based mathematics learning strategies.
\end{abstract}

\begin{tabular}{l}
\hline Keyword: Learning style; mathematics; learning guidance \\
\hline ABSTRAK \\
\hline Matematika masih dipandang sebagai mata pelajaran sulit dan tidak \\
menarik, karenanya membutuhkan strategi tertentu agar hasil belajar \\
menjadi optimal. Bimbingan Konseling sebagai bagian dari unsur \\
pendidikan berkontribusi dalam menunjang tujuan belajar. Belajar \\
berbasis gaya belajar dipandang menjadi salah satu solusi untuk \\
meningkatkan hasil belajar matematika. Penelitian ini bertujuan \\
mendeskripsikan pelaksanaan bimbingan belajar berbasis gaya \\
belajar yang mampu meningkatkan hasil belajar matematika serta \\
menguji efektivitas bimbingan belajar berbasis gaya belajar dalam \\
meningkatkan hasil belajar matematika. Penelitian ini menggunakan
\end{tabular}




\begin{abstract}
pendekatan mix method, dengan one group pretest posttest design. Data kualitatif diperoleh melalui angket, observasi dan wawancara ketika pelaksanaan bimbingan belajar, data kuantitatif diperoleh dari tes hasil belajar sebelum dan setelah kegiatan bimbingan belajar. Analisis data dilakukan menggunakan statistik deskriptif dan uji-t. Hasil penelitian menunjukkan bahwa sebelum dilaksanakan layanan bimbingan belajar, siswa belum mengetahui gaya belajarnya, cara belajar siswa secara otodidak, siswa kurang tertarik terhadap mata pelajaran matematika dan menganggap matematika sebagai pelajaran yang sulit. Hasil belajar matematika cenderung rendah. Pelaksanaan bimbingan belajar dilakukan dengan tahap: melakukan asesmen gaya belajar siswa, memberikan informasi dan diskusi tentang strategi belajar berbasis gaya belajar, praktik menerapkan strategi belajar berbasis gaya belajar. Melalui bimbingan belajar berbasis gaya belajar siswa menjadi lebih berminat belajar matematika serta terjadi peningkatan hasil belajar dari rerata prestes 46.25 menjadi 80.63. Hasil uji - t sebesar 11.296 dengan taraf signifkansi 0,5\%. Dengan demikian bimbingan berbasis gaya belajar efektif meningkatkan hasil belajar matematika, sehingga guru matematika perlu mengajarkan strategi belajar matematika berbasis gaya belajar.
\end{abstract}

Kata kunci: Bimbingan belajar; gaya belajar; matematika

\title{
PENDAHULUAN
}

Matematika merupakan mata pelajaran pokok yang diajarkan pada semua jenjang pendidikan. John A. Van de Walle (2002) mengatakan bahwa matematika merupakan ilmu yang membahas mengenai pola dan urutan. Ilmu ini banyak diterapkan dalam kehidupan sehari-hari. Harahap \& Syarifah (2015) mengemukakan bahwa mata pelajaran matematika sangat penting diajarkan di sekolah karena mampu mengembangkan kemampuan kognisi anak. Hal ini berati matematika juga mempunyai peran penting yang harus diperhatikan, karena perkembangan kognitif mempengaruhi kehidupan anak. Matematika merupakan bidang ilmu yang bersifat mengglobal. Merupakan ilmu milik dunia, dipelajari di seluruh dunia. Kehadiran matematika selalu dibutuhkan dalam kehidupan, tidak ada aktivitas atau tingkah laku manusia yang terlepas dari matematika (Kamarullah, 2017).

Tidak diragukan lagi, matematika mempunyai peranan penting dalam kehidupan. Pentingnya matematika diungkap oleh Cockroft (dalam Shadiq, 2014) yang mengungkapkan bahwa "It would be very difficult-perhaps impossible-to live a normal life in very many parts of the world in the twentieth century without making use of mathematics of some kind" yang berarti sangat-sangat sulit dan bisa dikatakan tidak mungkin untuk menjalani kehidupan yang normal di abad-20 tanpa adanya ilmu matematika.

Walau begitu, belum banyak orang menyadari pentingnya matematika dalam kehidupan. Kamarullah (2017) mengungkapkan bahwa kehadiran matematika dalam dunia pendidikan masih dianggap momok yang menakutkan oleh peserta didik yang 
mempelajarinya. Kehadiran matematika mampu mengembangkan daya nalar peserta didik agar memiliki kemampuan mengembangkan diri dalam bidang matematika maupun dalam bidang lainnya.

Hingga saat ini peserta didik masih mempersepsi matematika sebagai pelajaran yang sulit, sebagaimana penelitian Astuti, Siswati \& Setyawan (2002) yang menyimpulkan bahwa peserta didik menganggap matematika adalah pelajaran yang sulit dan menakutkan. Hal senada diungkapkan oleh Effendy, dkk. (2012) bahwa matematika telah dilebel sebagai pelajaran yang sulit, menakutkan, membosankan, yang kemudian menimbulkan persepsi negatif dalam belajar matematika. Hasil penelitian Siregar (2013) mengungkap 45\% responden mempersepsikan bahwa matematika adalah mata pelajaran yang dianggap cukup sulit.

Programme for International Students Assessment (PISA) melaporkan bahwa dari jumlah 540.000 siswa, Indonesia menduduki peringkat 63 dari 70 negara untuk matematika dengan skor 386. Oleh PISA manyatakan bahwa Indonesia masih tergolong rendah dalam penguasaan materi matematika (www.pisaindonesia.wordpress.com).

PISA merupakan suatu program penilaian skala dan survei 3 tahunan siswa berusia 15 tahun di seluruh dunia yang menilai sejauh mana peserta telah memperoleh pengetahuan dan ketrampilan yang utama dan penting untuk berpartisipasi penuh dalam kehidupan sosial dan ekonomi. PISA bertujuan meneliti secara berkala kemampuan siswa usia 15 tahun (kelas IX SMP dan Kelas X SMA) dalam menerapkan pengetahuan yang sudah mereka pelajari di sekolah yang berfokus pada bidang membaca (reading litercy), matematika (mathematics literacy), dan sains (science literacy) (Djunaedi, 2015).

Badan Penelitian dan Pengembangan (Litbank) Kemendikbud memaparkan bahwa nilai rata-rata Ujian Nasional (UN) Tahun 2020 pada jenjang SMP dan MTS masih dibawah standar. Rata-rata semua mata pelajaran UN masih berada di 52 poin, sedangkan standar kompetensi yang ditentukan adalah 55. Rata-rata dari semua mata pelajaran sebagai berikut; Bahasa Indonesia 65, Bahasa inggris 50, IPA 48, dan Matematika 46. Data tersebut menunjukkan bahwa matematika memiliki rata-rata yang paling rendah dibandingkan dengan mata pelajaran yang lain.

Kondisi ini tidak bisa dibiarkan terus berlanjut. Perlu upaya-upaya untuk menumbuhkan minat belajar pada mata pelajaran matematika. Perlu keterlibatan seluruh komponen pendidikan untuk mendongkrak hasil belajar siswa pada mapel matematika yang sangat dibutuhkan dalam kehidupan tersebut. 
Bimbingan dan Konseling (BK) merupakan salah satu komponen sekolah mempunyai peran penting dalam membantu tujuan pendidikan sebagaimana dimanatkan dalam UU No.22 tahun 2013. Salah satu tujuan bimbingan dan konseling adalah membantu peserta didik meraih tujuan belajarnya dan mengatasi hambatan dalam belajar (Thohirin, 2014). Tujuan ini gayung bersambut dengan tujuan guru mata pelajaran yaitu agar peserta didik menguasai materi pelajaran serta mencapai ketuntatan minimum. Karena itu perlu adanya kolaborasi antara guru mata pelajaran dengan guru Bimbingan dan Konseling. Bimbingan konseling bertujuan membantu guru menemukan strategi belajar yang tepat (Hastini, 2014).

Salah satu layanan dalam bimbingan dan konseling adalah Bimbingan Belajar. Bimbingan belajar merupakan upaya pemberian bantuan dari guru Bimbingan dan Konseling kepada peserta didik dalam mengatasi masalah-masalah belajar. Bimbingan belajar merupakan suatu bidang bimbingan yang ditujukan untuk membantu peserta didik dalam mengenal, menumbuhkan, dan mengembangkan, sikap kebiasaan belajar yang baik untuk menguasai pengetahuan serta ketrampilan untuk menyiapkan pendidikan yang lebih tinggi (Prayitno, 2015).

Menurut Thahir dan Hidriyanti (2014) dalam penelitiannya menyimpulkan bahwa layanan bimbingan belajar mempunyai pengaruh terhadap peningkatan prestasi belajar pada peserta didik. Dengan begitu layanan bimbingan belajar dapat menjadi solusi yang mendukung kegiatan belajar peserta didik. Layanan bimbingan belajar bisa dilakukan dengan berbagai cara salah satunya adalah membimbing siswa untuk belajar sesuai gaya belajarnya. Setiap anak memiliki ciri khas tersendiri bagaimana mereka belajar, sehingga perlu anak dapat belajar secara optimal sesuai kapasitas yang dimiliki.

Gaya belajar adalah strategi atau cara yang lebih disukai dalam memproses pengalaman dan informasi (Bob Samples, 2002). Sementara Winkel (2005) menyatakan bahwa gaya belajar merupakan cara belajar yang khas bagi siswa. Suparman (2010) melengkapi pendapat sebelumnya bahwa gaya belajar merupakan kombinasi bagaimana individu menyerap, kemampuan mengatur dan mengolah informasi dalam belajarnya.

Kenyataannya masih banyak siswa belajar secara alamiah, melakukan cara belajar berdasarkan kebiasaan yang sudah dilakukan selama bertahun-tahun. Cara belajar yang dilakukan peserta didik bisa diperoleh dari mengamati cara kakak atau orang lain belajar, bisa karena mengikuti instruksi dari orangtua atau guru bagaimana cara belajar. Karena itu cara belajar peserta didik adakalanya tidak sesuai dengan gaya belajarnya. Rendahnya 
prestasi belajar peserta didik bisa jadi bukan karena rendahnya daya serap dalam bidang matematika, namun karena penggunaan stratagi belajar yang salah.

Peserta didik membutuhkan pengetahuan dan pemahaman mengenai cara belajar yang paling nyaman dan mengesankan sesuai dengan gaya belajar yang dimilikinya. Bire (2014) mengungkapkan bahwa gaya belajar akan memberi kunci dalam belajar, sehingga kenyaman belajar dapat disesuaikan dengan lingkungan dan tipe yang dimilikinya. Menurut Halim (2012) dalam penelitiannya menyimpulkan bahwa penerapan strategi pembelajaran yang sesuai dengan karakteristik siswa dan materi pelajaran akan mempengaruhi hasil belajar yang diperoleh siswa. Oleh karena itu dianjurkan bagi guru-guru agar mempertimbangkan karaktristik siswanya terutama dalam hal gaya belajar sebelum memilih strategi pembelajaran yang akan diterapkan dalam mengajarkan pokok bahasan tertentu, sebab kecenderungan gaya belajar yang dimiliki peserta didik juga turut memberi pengaruh yang berbeda terhadap hasil belajar peserta didik.

Penelitian tentang penerapan gaya belajar pernah dilakukan oleh Widyawati (2016) yang menyimpulkan bahwa gaya belajar berpengaruh terhadap prestasi hasil belajar mahasiswa program studi pendidikan matematika. Penelitian ini dilakuka n pada mahasiswa dan tidak spesifik pada hasil belajar matematika. Penelitian Khoerun, dkk. (2014) juga menyimpulkan bahwa gaya belajar mempunyai hubungan dan berpengaruh signifikan terhadap prestasi belajar peserta didik. Gaya belajar mempunyai kontribusi sebesar 52\% terhadap prestasi belajar peserta didik. Penelitian ini juga tidak spesifik pada mata pelajarn matematika, sedangkan kajian dalam penelitian ini difokuskan pada peningkatan hasil belajar matematikapada siswa SMP.

Berdasarkan uraian diatas, penelitian ini memaparkan pelaksanaan Layanan Bimbingan Belajar berbasis gaya belajar untuk meningkatkaan hasil belajar siswa pada mata pelajaran matematika.

\section{METODE}

Penelitian ini merupakan penelitian eksperimen dengan menggunakan desain one group pretest-posttest design, yaitu mengukur hasil belajar sebelum dan setelah pelaksanaan tretmen berupa bimbingan belajar berbasis gaya belajar. Subjek penelitian ini adalah siswa SMP kelas VII sebanyak 16 orang. Data kualitatif diperoleh melalui wawancara dan observasi, sedangkan data kuantitatif diperoleh melalui tes hasil belajar matematika yang disusun oleh guru dan tes gaya belajar dikembangkan dari peneliti sebelumnya yang 
meliputi gaya belajar visual, audory dan kinestetik. Wawancara bertujuan mengumpulkan data awal tentang kesulitan yang dialami siswa dalam belajar matematika serta cara belajar siswa Observasi digunakan untuk mengungkap kegiatan praktik menerapkan strategi belajar ketika mengikuti pelajaran dan mendalami materi matematika. Tes gaya belajar dimodifikasi dari instrumen yang dikembangkan oleh peneliti sebelumnya yang mengungkap tiga tipe gaya belajar yaitu gaya belajar visual, audory dan kinestetik. Teknik analisis data menggunakan analisis konten untuk menganlisis kesulitan dalam belajar matematika, persepsi siswa terhadap matematika. Statistik deskriptif digunakan untuk menganlisis gaya belajar siswa dan t-test untuk menguji efektivitas layanan Bimbingan Belajar berbasis gaya belajar terhadap peningkatan hasil belajar.

\section{HASIL DAN BAHASAN}

\section{Persepsi Siswa terhadap Matematika}

1. Matematika tidak menarik

Sebelum pelaksanaan bimbingan belajar, ditemukan data persepsi siswa terhadap pelajaran matematika masih negatif. Sebagian besar subjek menyatakan matematika merupakan pelajaran yang tidak menyenangkan, siswa lain mengatakan kurang tertarik terhadap pelajaran matematika, merasa bosan ketika mengikuti pelajaran matematika. Alasan subjek tidak tertarik matematika karena cara guru mengajar membosankan. Temuan ini sejalan dengan pendapat Kamarullah (2017) bahwa matematika masih dianggap sebagai momok. Alasan subjek tidak tertarik matematika karena cara guru mengajar membosankan. Persepesi berpengaruh terhadap pikiran dan tindakan, persepsi negatif terhadap matematika akan mempengaruhi daya juangnya untuk menyelasaikan tugas-tugas terkait matematika. Persepsi bahwa matematika tidak menarik sangat sangat merugikan siswa itu sendiri.

2. Matematika sulit

Hampir semua subjek mengatakan bahwa mata pelajaran matematika sulit, karena harus menghafalkan rumus-rumus. Untuk menjawab satu harus mengetahui banyak rumus, harus banyak menghafal. Matematika dianggap sulit karena selalu menghitung, harus fokus, banyak angka. Berbagai penelitian mengungkap bahwa matematika dipandang sebagai pelajaran yang sulit (Astuti, Siswati \& Setyawan, 2002 dan Effendy, dkk., 2012). Pandangan bahwa matematika sebagai mata pelajaran yang sulit justru akan menyulitkan siswa itu sendiri, karena berdasarkan neouro science, apa yang dipikirkan itulah yang akan terjadi. Kesulitan yang dialami siswa ketika mengikuti pelajaran matematika diperberat oleh persepsinya tentang matematika. 


\section{Strategi Belajar Siswa}

Semua subjek penelitian belum pernah mendengar istilah gaya belajar. Cara belajar siswa selama ini dilakukan secara otodidak, yaitu membaca buku, menghafalkan rumus, mendengarkan penjelasan guru dan mengerjakan soal-soal latihan. Siswa belum mengetahui gaya belajar masing-masing dan tidak pernah menerapkan strategi belajar tertentu untuk bisa memahami pelajaran. Berbagai literatur menyebutkan bahwa strategi belajar sangat penting guna meraih sukses dalam belajar. Bertens (2005) menyatakan menguasai strategi belajar yang efektif sangat penting bagi mahasiswa agar dapat menempuh studi dengan sukses dan optimal. Hasil penelitian Sriyanti (2021) menyimpulkan bahwa keberhasilan belajar sesorang bukan ditentukan oleh faktor kecerdasan melainkan lebih pada keterampilan belajarnya.

\section{Hasil Belajar Matematika}

Hasil tes hasil belajar sebelum pelaksanaan bimbingan belajar berbasis gaya belajar ditemukan sebagaimana terlihat pada grafik 1 . Terlihat bahwa hasil belajar siswa masih di bawah standar ketuntasan yang diharapkan. Data pada grafik 1 adalah hasil belajar sebelum dilakukan layanan bimbingan belajar berbasis gaya belajar. Terlihat pada grafik bahwa hasil belajar siswa masih rendah, dibawah kriteria ketuntasan minimun yang tetapkan sekolah.

\section{Langkah Layanan Bimbingan Belajar Berbasis Gaya Belajar}

Pelaksanaan bimbingan belajar mengikuti langkah pelaksanaan umum pelaksanaan bimbingan konseling, yaitu meliputi asesmen, tretmen dan evaluasi sebagaimana diungkap Sriyanti (2020) bahwa langkah pelaksanaan bimbingan konseling meliputi identifikasi, asesmen, layanan bantuan atau tretmen dan evaluasi. Sedangkan Salahuddin (2020) menuliskan langkah bimbingan dan konseling meliputi identifikasi, diagnosis, prognosis, terapi, evaluasi dan follow-up. Berdasarkan tahap pelaksanaan layanan bimbingan konseling tersebut, maka pelaksanaan bimbingan belajar berbasis gaya belajar mengikuti Langkah-langkah berikut:

1. Melakukan asesmen gaya belajar siswa

Langkah awal sebelum melaksanakan bimbingan belajar adalah melakukan asesmen terhadap gaya belajar siswa. Asesmen merupakan langkah awal pelaksanaan bimbingan sebagaimana diungkap Sriyanti (2020). Asesmen dilakukan dengan memberikan tes gaya belajar guna mengungkap tiga gaya belajar pada siswa. Tes gaya belajar ini menggunakan instrumen yang dimodifikasi dari peneliti sebelumnya dan sudah divalidasi pakar. 
Berdasarkan analisis tes gaya belajar ditemukan tiga gaya belajar siswa yaitu gaya belajar visual, gaya belajar auditori dan gaya belajar kinestetik. Data gaya belajar siswa terlihat pada grafik 2.

2. Mengelompokkan siswa berdasar gaya belajar

Berdasarkan data gaya belajar, selanjutnya siswa dikelompokkan berdasarkan gaya belajarnya. Pengelompokkan berdasarkan gaya belajar adalah siswa yang mempunyai gaya belajar visual belajar bersama dalam satu kelompok, demikian untuk siswa yang mempunyai gaya belajar auditori dan kinestetik. Pengelompokkan ini bertujuan memudahkan guru BK memberikan bimbingan dalam menerapkan strategi belajar yang sesuai dengan gaya belajar masing-masing siswa. Masing-masing gaya belajar memerlukan strategi belajar yang berbeda, sehingga data gaya belajar siswa diatas menjadi dasar guru BK dan guru Matematika mengelompokkan siswa ketika memberikan layanan bimbingan kelompok untuk mempraktikkan strategi belajar sesuai gaya belajar masing-masing siswa.

Suparman (2010) menuliskan ciri seseorang yang mempunyai gaya belajar visual yaitu, rapi, teratur, sanget memperhatikan penampilan, bicaranya cepat, pengeja ulung, mudah mengingat apa yang dilihat dari pada didengar, lebih suka membaca daripada dibacakan, mudah untuk membaca peta, kurang mudah untuk mengingat pesan verbal, sehingga ketidak menyampaikan mereka cenderung lupa keseluruhan atau tidak utuh, lebih suka melakukan demonstrasi daripada berpidato. Siswa yang mempunyai ciri belajar dalam satu kelompok. Ada 4 siswa yang menunjukkan ciri bergaya belajar visual, belajar dalam satu kelompok.

Sebelas siswa yang mempunyai ciri suka berbicara dengan diri sendiri, fasih dalam berbicara, senang mendengarkan, lebih mudah mengingat materi pelajaran yang didengarkan, senang berdiskusi, senang terhadap suara yang berirama dimasukkan dalam satu kelompok. Suparman (2010) nyatakan bahwa bahwa orang dengan ciri tersebut adalah orang yang mempunyai gaya belajar auditori. Sementara satu orang siswa yang mempunyai gaya belajar kinestetis belajar sendiri.

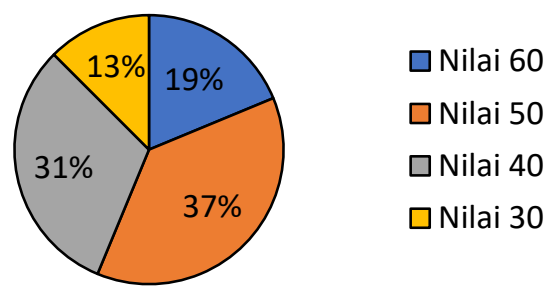

Grafik 1. Nilai Pretes Matematika 


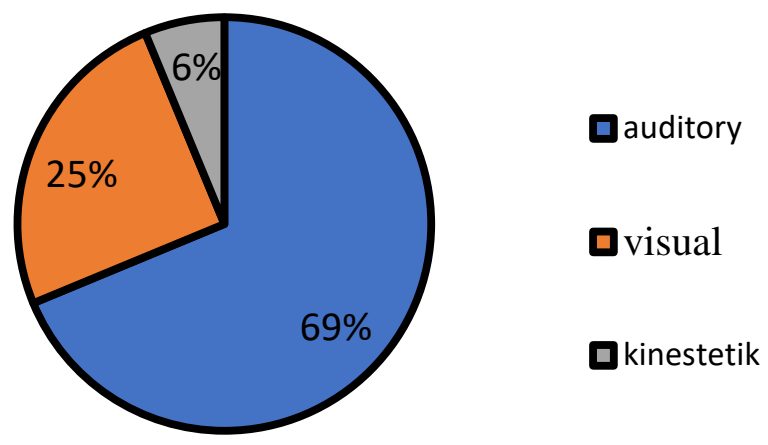

\section{Grafik 2. Hasil Asesmen Gaya Belajar Siswa}

\section{Pelaksanaan layanan bimbingan belajar berbasis gaya belajar}

Pelaksanaan layanan bimbingan belajar berbasis gaya belajar dilakukan melalui beberapa strategi. Setrategi yang dilakukan diantaranya: a) kolabaorasi, b) memanfaatkan media belajar, c) bimbingan belajar klasikal, d) bimbingan kelompok, e) bimbingan individual. Secara rinci pelaksanaan layanan bimbingan berbasis gaya belajar, sebagai berikut.

a. Kolaborasi

Pelaksanaan layanan bimbingan belajar berbasis gaya belajar dilaksanakan secara kolaboratif, yaitu antara guru BK dengan guru Matematika. Kaloborasi dalam layanan bimbingan dan konseling berpijak pada salah satu prinsip bimbingan, yaitu bimbingan sebagai usaha bersama (Departemen Pendidikan Nasional, 2007), artinya bimbingan bukan hanya menjadi tanggung jawab konselor, melainkan perlu kerjasama dengan pihak lain. Demikian juga dengan Biasco (dalam Yusuf, 2009) menyatakan bahwa bimbingan akan berlangsung efektif apabila ada kerja sama dengan personil sekolah.

Pentingnya kolaborasi juga diungkap oleh Lassonde (2010) yang menyatakan bahwa kegiatan pendidikan yang dilaksanakan secara kolaboratif dapat meningkatkan aktivitas belajar siswa dan dapat berkembang secara profesional. Demikian juga dengan hasil penelitian Sholehuddin (2010) yang menyimpulkan bahwa pembelajaran yang berbasis bimbingan kolaboratif dapat lebih memberdayakan.

Bimbingan belajar berbasis gaya belajar diberikan secara klasikal, secara kelompok serta menggunakan pendekatan individual. Pendekatan individual diberikan pada sesi akhir untuk menguatkan penerapan gaya belajar siswa ketika mendalami materi matematika. Metode yang digunakan dalam layanan bimbingan belajar adalah ceramah, diskusi, tanya 
jawab, pemberian tugas dan refleksi. Sedangkan materi bimbingan belajar meliputi strategi belajar yang tepat untuk tiga gaya belajar dan media yang digunakan untuk menunjang belajar.

b. Memanfaatkan Media Belajar

Pemilihan media sangat penting dalam belajar, pemilihan yang tepat akan membuat siswa mampu dengan mudah menerima informasi yang disampaikan. Media juga dapat menghinadri kebosanan sehingga akan membuat siswa selalu tertarik untuk mengikuti pembelajaran. Setianingrum (2017) menyatakan bahwa dalam mengajar seorang pengajar akan selalu membutuhkan metode dan media pengajaran yang kreatif sehingga siswa mampu dan mudah menyerap dengan baik ilmu yang disampaikan.

Pemilihan media yang digunakan untuk menunjang daya serap siswa terhadap materi pelajaran yang sesuai dengan 3 gaya belajar adalah sebagai berikut.

1) Media ajar gaya belajar visual

Media yang digunakan untuk siswa dengan gaya belajar visual menggunakan gambar, slide powerpoint dengan tulisan berwarna-warni, grafik, dan juga ilustrasi. Membuat slide powerpoint yang dibuat menarik dengan meyertakan contoh gambar serta tulisan. Siswa yang mempunyai gaya belajar visual secara tidak langsung akan selalu memperhatikan bagaimana gerak-gerik guru yang sedang menjelaskan didepan, ini sejalan dengan pendapat Setianingrum (2017) bahwa anak dengan gaya belajar akan selalu memperhatikan setiap gerak yang dilakukan oleh gurunya di depan sehingga guru juga dapat dijadikan media yang digunakan anak dengan gaya belajar visual untuk belajar.

2) Media ajar gaya belajar auditori

Media yang digunakan untuk siswa dengan gaya belajar auditori yaitu berupa video dan rekaman suara. Disaat guru Matematika menjelaskan materi pelajaran, disarankan siswa agar merekam apa yang dijelaskan agar dapat mendengarkannya kembali ketika sedang belajar sendiri. Dengan begitu siswa dapat mendengarkan kembali rekama apabila telah lupa pada materi yang telah diberikan. Sebagaimana pernyataan Ula (2013) bahwa siswa dengan gaya belajar auditori dilakukan dengan mendengar kaset, audio, ceramah, diskusi, debat dan instruksi atau perintah secara verbal.

3) Media ajar gaya belajar Kinestetik

Media yang digunakan untuk siswa dengan gaya belajar kinestetik adalah anak itu sendiri, yaitu dengan cara belajar dengan bergerak, bekerja dan menyentuh. Anak dengan 
gaya belajar kinestetik akan leboh mudah memahami suatu materi jika ia ikut serta atau terlibat didalam kegiatan.

c. Bimbingan belajar klasikal

Bimbingan belajar klasikal diikuti oleh semua siswa (16 orang) serta guru mata pelajaran matematika. Bimbingan ini diberikan pada awal sesi, yang bertujuan untuk memberikan informasi tentang macam-macam gaya belajar dan implikasinya dalam kegiatan belajar, memberikan informasi dan mendiskusikan tentang gaya belajar masingmasing siswa berdasarkan tes gaya belajar, menjelaskan tentang strategi belajar yang tepat untuk masing-masing gaya belajar dilanjutkan tanya jawab, memaparkan media yang digunakan untuk menunjang strategi belajar. Pemahaman siswa tentang gaya belajar dikuatkan dengan pemutaran video tentang strategi belajar berbasis gaya belajar. Yulneni (2017) dalam temuannya mengungkapkan bahwa bimbingan klasikal terbukti dapat memberikan pengaruh terhadap aktivitas belajar siswa serta hasil belajar lebih meningkat. Hal tersebut membuktikan bahwa melalui bimbingan klasikal siswa dapat meningkatkan aktivitas belajar menjadi lebih baik, sehingga bimbingan klasikal bagus untuk diberikan kepada siswa supaya aktivitas dan hasil belajar siswa dapat meningkat.

d. Bimbingan kelompok

Bimbingan belajar secara kelompok diberikan setelah siswa menerapkan strategi belajar berdasar gaya belajar ketika menerima materi pelajaran dari guru Matematika sebagaimana yang sudah dijelaskan dalam bimbingan secara klasikal. Tatiek (2001) mengemukakan bahwa bimbingan kelompok dapat memberikan kesempatan kepada siswa untuk belajar mengenai hal-hal penting yang dapat berguna bagi pengarahan dirinya yang berkaitan dengan masalah pendidikan, pekerjaan maupun pribadi dan sosial. Bimbingan kelompok ini diberikan berdasarkan kelompok gaya belajar yang dimiliki siswa. Siswa dibagi menjadi 3 kelompok, yaitu kelompok siswa dengan gaya belajar visual sebanyak 4 orang, kelompok siswa dengan gaya belajar auditory 11 orang dan siswa dengan gaya belajar kinestetik satu orang. Guru BK bekerja sama dengan guru matematika mendampingi belajar siswa dengan menerapkan strategi belajar sesuai gaya belajar masing-masing ketika mendalami materi pelajaran.

Strategi belajar untuk masing-masing gaya belajar adalah sebagai berikut: 1) Gaya belajar visual, pada gaya belajar ini disarankan guru menggunakan grafik, tabel, peta, multimedia lain untuk membantu siswa yang mempunyai gaya belajar visual, Berdasarkan hal tersebut, bimbingan belajar untuk siswa dengan gaya belajar visual ini dilakukan dengan 
cara sebagai berikut: mendengarkan dan mencatat penjelasan guru, membuat mind mapping, menandai bagian-bagian yang penting dalam buku menggunakan spidol warna, belajar menggunakan media gambar berwarna, melihat video guna menguatkan pemahaman, membuat tabel dan grafik untuk menyederhakan materi, menulis rumus-rumus di buku catatan dan diwarnai dengan warna-warna mencolok; 2) Gaya belajar auditorial, siswa yang didiagnosis memiliki gaya belajar auditory sebanyak 11 orang menerapkan strategi belajar untuk gaya auditory. Strategi belajar gaya auditory dilakukan dengan cara : mencari suasana yang tenang ketika belajar, menghindari kegaduhan, belajar sambil mendengarkan musik yang disukai, bisa meminta guru menjelaskan materi secara face to face atau melakukan rekaman audio ketika guru memberikan penjelasan, mendengarkan kembali rekaman penjelasan guru, membaca materi dengan mengeluarkan suara, meminta bantuan kepada teman untuk membacakan materi, mengajak teman untuk berdiskusi kelompok membahas pelajaran, menghafal rumus dengan membaca secara berulang-ulang; dan 3) Gaya belajar kinestetik, siswa yang memiliki gaya belajar kinestetik ada satu orang. Siswa ini menerapkan strategi belajar sebagai berikut : belajar di luar ruangan, menggunakan alat peraga ketika belajar, jika merasa bosan, maka istirahat sejenak setelah itu baru dilanjutkan lagi, belajar sambil memainkan sesuatu (seperti memutar-mutar pencil, menggoyangkan-goyangkan tangan), bermain sambil belajar ( belajar dilakukan sambil memainkan robot, sambil memainkan boneka), belajar sambil makan sesuatu seperti permen karet, mencoba mempraktikkannya langsung materi yang dipelajari dalam kehidupan, menghafal rumus dan materi sambil berjalan (Ula, 2013; Suparman, 2010).

e. Bimbingan Individual

Bimbingan individual dilakukan pada siswa yang masih kesulitan menyelesaikan soal latihan dan siswa mengalami kesulitan menerapkan strategi belajar berdasarkan gaya belajarnya. Pada dasarnya bimbingan individual dengan bimbingan pribadi mempunyai pengertian yang sama. Surya (2003) mengungkapkan bahwa tujuan dilakukannya bimbingan individual agar siswa dapat mengembangkan potensi dan kemampuan yang ada pada dirinya sendiri supaya menjadi anak yang mandiri dengan memanfaatkan segala kekuatan yang dimilikinya untuk dapat dikembangkan, penerimaan diri, serta perwujudan diri untuk mencapai perkembangan yang optimal. Berdasarkan hasil diagnosis selama bimbingan individual ditemukan data bahwa siswa saat mengerjakan latihan kurang fokus dan siswa belum menerapkan strategi secara optimal. 


\section{Hasil Layanan Bimbingan Belajar Berbasis Gaya Belajar}

Layanan bimbingan belajar berbasis gaya belajar membawa beberapa perubahan dalam suasana belajar siswa. Perubahan tersebut dirasakan oleh siswa dan guru Matematika. Setelah kegiatan bimbingan belajar, siswa menjadi merasa senang dan tertarik belajar matematika, menjadi lebih mudah memahami materi pelajaran dan menyelesaikan soal latihan. Belajar matematika menjadi mudah dan menyenangkan. Berdasarkan hasil postes ditemukan adanya peningkatan hasil belajar sebagaimana terlihat pada tabel 1 . Tabel 1 berikut menggambarkan perbandingan hasil belajar matematika dari pretest dan posttest. Terlihat dari tabel 1 bahwa rerata hasil belajar sebelum layanan bimbingan sebesar 46.25 , sedangkan rerata hasil belajar setelah layanan bimbingan meningkat menjadi 80.63. Adapun peningkan hasil belajar dari pretest dengan hasil belajar setelah pelaksanaan bimbingan belajar terlihat pada grafik 3 .

Tabel 1. Perbandingan Hasil Pretest dan Postest

\begin{tabular}{lcccc}
\hline No. & Subjek & Nilai Prestest & $\begin{array}{c}\text { Nilai } \\
\text { Postest }\end{array}$ & Gain Score \\
\hline 1. & EV & 50 & 80 & 30 \\
\hline 2. & RDY & 60 & 70 & 10 \\
\hline 3. & FZ & 50 & 80 & 30 \\
\hline 4. & MMFM & 40 & 90 & 50 \\
\hline 5. & R & 40 & 80 & 40 \\
\hline 6. & ARK & 40 & 80 & 40 \\
\hline 7. & LR & 50 & 80 & 30 \\
\hline 8. & D & 60 & 90 & 30 \\
\hline 9. & ADD & 30 & 80 & 50 \\
\hline 10. & DA & 40 & 80 & 40 \\
\hline 11. & A & 40 & 80 & 40 \\
\hline 12. & DB & 50 & 70 & 20 \\
\hline 13. & RS & 50 & 70 & 20 \\
\hline 14. & NJM & 50 & 80 & 30 \\
\hline 15. & SAM & 30 & 80 & 50 \\
\hline 16. & W & 60 & 100 & 40 \\
\hline$\sum$ & & 740 & 1290 & 550 \\
\hline Mean & & 46,25 & 80,63 & 34,38 \\
\hline Minumum & & 30 & 70 & 10 \\
\hline Maximum & & 60 & 100 & 50 \\
\hline & & & & \\
\hline
\end{tabular}




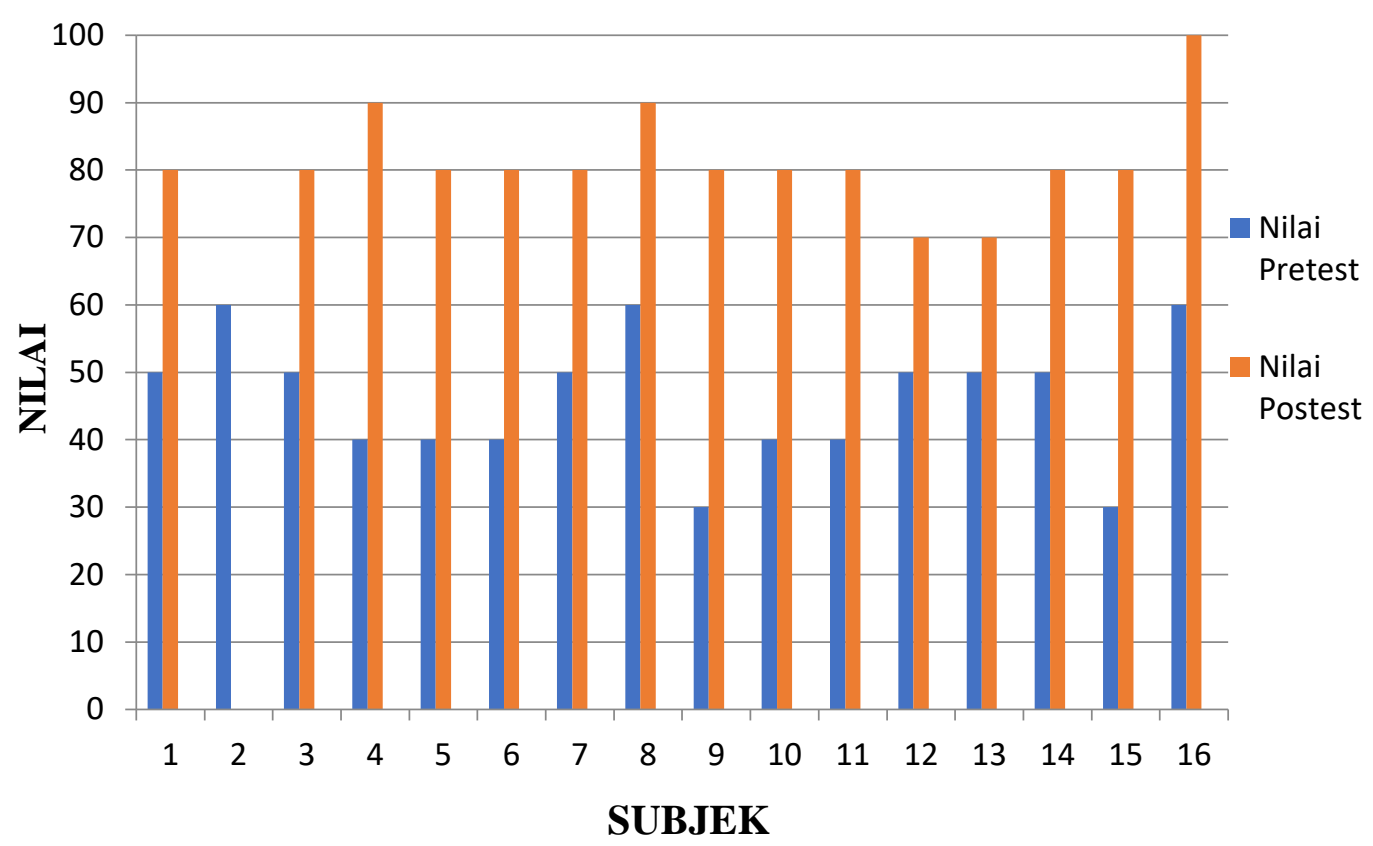

Grafik 3. Grafik perbandingan nilai pretest dan postest

\section{Uji Hipotesis}

Uji hipotesis yang digunakan dalam penelitian ini uji paired sample $t$ test yang bertujuan untuk mengetahui adanya perbedaan rerata antara pretes dan postes hasil belajar matematika. Berdasarkan hasil uji t pada subjek sebanyak N 16, ditemukan nilai sstandar deviasi pada pretest sebesar 9,574 dan posttest 7,719, dan yang terakhir adalah std.error mean untuk pretest sebesar 2,394 dan untuk posttest sebesar 1,930, dengan nilai t sesebar 11.926. Berdasarkan hasil uji-t dapat disimpulkan bahwa bimbingan belajar berbasis gaya belajar efektif untuk meningkatkan hasil belajar siswa pada mata pelajaran matematika.

\section{KESIMPULAN}

Penelitian ini menyimpulkan bahwa layanan bimbingan belajar berbasis gaya belajar dapat mengubah persepsi siswa terhadap mata pelajaran matematika sebagai mata pelajaran yang sulit dan menakutkan. Layanan bimbingan juga dapat meningkatkan minat dan hasil belajar siswa pada mata pelajaran matematika. Kesimpulan penelitian ini melebarkan wawasan bahwa persepsi negatif siswa terhadap pelajaran dapat diubah, bahwa minat belajar dapat ditingkatkan. Data menunjukkan bahwa prestasi belajar siswa pada mata pelajaran matematika secara nasional masih rendah. Rendahnya hasil belajar siswa tersebut tidak selalu bersumber dari lemahnya daya serap, namun bisa bersumber dari strategi belajar yang salah. Strategi belajar menjadi salah satu kunci keberhasilan belajar. Karena itu 
penting bagi guru untuk terus melakukan inovasi dan kolaborasi dengan berbagai orang yang ekspert untuk mengoptimalkan hasil belajar siswa.

\section{DAFTAR RUJUKAN}

Anas, A., Munir, Nilam, Permatasari. (2014). Pengaruh Gaya Belajar VAK Terhadap Hasil Belajar Matematika Siswa. Prosiding Seminar Nasional, 2(1), 233-240.

Bertens, K. (2005). Metode Belajar untuk Mahasiswa, Beberapa petunjuk bagi mahasiswa baru. Jakarta: Gramedia.

Bire, A. L., Uda, G., \& Josua, B. (2014). Pengaruh Gaya Belajar Visual, Auditorial, dan Kinestetik terhadap Prestasi Belajar Siswa. Jurnal Kependidikan, 44(2), 168-174.

Damayanti, N. (2012). Buku Pintar Panduan Bimbingan dan Konseling. Yogyakarta: Araska.

Departemen Pendidikan Nasional. (2008). Rambu-rambu Penyelenggaraan Bimbingan dan Konseling dalam Jalur Pendidikan Formal. Jakarta: Departemen Pendidikan Nasional.

DePorter, B. \& Hernacki, M. (2000). Quantum Learning. Edisi Revisi. Bandung: Kaifa.

Halim, A. (2012). Pengaruh Strategi Pembelajaran dan Gaya Belajar terhadap Hasil Belajar Fisika Siswa SMPN 2 Secanggang Kabupaten Langkat. Jurnal Tabularasa PPS UNIMED, 9(2), 141-158.

Hartati, L. (2013). Pengaruh Gaya Belajar dan Sikap Siswa pada PelajHastiani. (2014). Model Kolaborasi Guru Bimbingan Konseling Dengan Guru Mata Pelajaran Untuk Meningkatkan Ketrampilan Komunikasi Interpersonal Siswa Cerdas Istomewa. Jurnal Edukasi, 1(1), 63-74

Kamarullah. (2017). Pendidikan Matematika di Sekolah Kita. Jurnal Pendidikan dan Pembelajaran Matematika, 1 (1): 21-32

Lassonde, C.A \& Susan E.I. (2010). Teacher Collaborative for Professional Learning, Facilitating Study, Reseach and Inquiry Communities. San Fransisco: John Wiley and Sons.

Merpaung, J. (2015). Pengaruh Gaya Belajar Terhadap Prestasi Belajar. Jurnal Kopasta, $2(2), 13-17$

Muro, J. J. \& Kottman, T. (1995). Guidance and Counseling in the Elementary and Middle Schools: A Practical Approach. Madison WI: WCB Brown \& Benchmark Publishers.

Nurkolis. (2013). Pendidikan dalam Upaya Memajukan Teknologi. Jurnal Kependidikan, 1 (1), 24-44.

Prayitno \& Erman Amti. (2015). Dasar-dasar Bimbingan dan Konseling. Jakarta: PT Rineka Cipta.

Romlah, T. (2001). Teori dan Praktek Bimbingan Kelompok. Malang: Universitas Negeri malang, Cet Ke-1.

Septiana, A. (2016). Hubungan Gaya Belajar dan Persepsi Siswa Tentang Metode Mengajar Guru Terhadap Prestasi Belajar Matematika pada Siswa-siswi Kelas XI SMA Negeri 1 Sangatta Utara Kutai Timur. e-Journal Psikologi, 4(2), 260-270.

Setianingrum, M. (2017). Penggunaan Variasi Media Ajar Terhadap 3 Gaya Belajar Siswa dalam Pembelajaran Bahasa Jepang. Jurnal Pendidikan dan Pengajaran Bahasa Jepang, 2(1), 1-8

Shadiq, F. (2014). Pembelajaran Matematika (Cara Meningkatkan Kemampuan Berpikir Siswa). Yogyakarta: Graha Ilmu. 
Sholehuddin, M. (2010). Emproving Disadvantaged Kondergartens Through GuidanceBased Teaching. Journal: Education, 4(2), 107-119.

Surya, M. (2003). Psikologi Konseling. Bandung: CV Pustaka Bani Quraisi.

Siagian, M. D. (2016). Kemampuan koneksi Matematika dalam Pembelajaran Matematika. Journal of Mathematics Education and Science, 2(1), 58-67.

Sriyanti, L. (2021). Mengoptimalkan Prestasi Mahasiswa Melalui Pendekatan Self Management. Retrieved November 29, 2021, from perpus iain salatiga website: http://e-repository.perpus.iainsalatiga.ac.id/12560/.

Sriyanti, L. (2020). Bimbingan Konseling bagi Anak Berkebutuhan Khusus. Yogyakarata: Trusmedia.

Suharsimi, A. \& Lia, Y. (2012). Manajemen Pendidikan. Yogyakarta: Aditya Media.

Suparman S. (2010). Gaya mengajar yang menyenangkan siswa. Yogyakarta: Pinus.

Tahir, W. A. (2017). Pengembangan Manajemen Sumber Daya Manusia Terhadap Peningkatan Mutu Pendidikan. Jurnal Inspiratif Pendidikan, 6(1), 1-14.

Thahir, Andy. (2014). Pengaruh Bimbingan Belajar Terhadap Prestasi Belajar Siswa Pondok Pesantren Madrasah Aliyah Al-Utrujiyyah Kota Karang. Jurnal Bimbingan dan Konseling e-journal. 1(2): 55-66

Tohirin. (2014). Metode Penelitian Kualitatif dalam Pendidikan dan Bimbingan Konseling. Jakarta: PT Raja Grafindo Persada.

Widyanti, F. D. (2016). Pentingnya Mengetahui gaya Belajar Siswa dalam Kegiatan Pembelajaran di Kelas. Jurnal Erudio, 2(1), 7-21.

Widyawati. (2016). Pengaruh Gaya Belajar Terhadap Prestasi Belajar Mahasiswa Program Studi Pendidikan Matematika (IAIM NU) Metro. Jurnal Pendidikan Matematika, 7 (1), 107-114.

Winkel,W.S. (2005). Bimbingan dan Konseling di Institusi Pendidikan. Yogyakarta: Media Abadi.

Wulandari, R. (2011). Hubungan Gaya Belajar dengan Prestasi Belajar Mahasiswa Semester IV Program Studi D IV Kebidanan Universitas Sebelas Maret. Jurnal Kesmasdaka, 2(1), 45-52

Yulneni, A. (2017). Pengaruh Layanan Bimbingan Klasikal Terhadap Aktivitas Belajar Siswa kelas II SMK Negeri 2 Gorontalo. (Unpublished thesis) Universitas negeri Gorontalo, Gorontalo, Indonesia.

Yusuf, S. (2009). Program Bimbingan dan Konseling di Sekolah. Bandung: Rizqi Press.

Zahri, T., Nuzilla, A., Murri, Y., \& Neviyarni, S. (2017). Hubungan Gaya Belajar dan Ketrampilan Belajar Dengan Hasil Belajar Mahasiswa. Ejournal UNP, 6(1), 18-23. 